\title{
AMMONIATION OF RICE STRAW AND SUPPLEMENTATION OF Paraserianthes falcataria AND Sapindus rarak ON IN VITRO RUMEN FERMENTATION AND METHANE PRODUCTION
}

\section{AMONIASI JERAMI PADI DAN SUPLEMENTASI SENGON LAUT (Paraserianthes falcataria) DAN LERAK (Sapindus rarak) TERHADAP FERMENTASI RUMEN DAN PRODUKSI GAS METANA SECARA IN VITRO}

\author{
Anuraga Jayanegara ${ }^{1 *}$, Nanang Krisnawan ${ }^{1}$, Yeni Widyawati ${ }^{2}$ and Asep Sudarman ${ }^{1}$ \\ ${ }^{1}$ Department of Nutrition and Feed Technology, Faculty of Animal Science, Bogor Agricultural University, \\ Bogor, 16680 \\ ${ }^{2}$ Indonesian Research Institute for Animal Production, Bogor, 16002
}

Submitted: 1 June 2017, Accepted: 28 September 2017

\begin{abstract}
This study aimed to observe the effects of rice straw ammoniation and supplementation of Paraserianthes falcataria and Sapindus rarak on rumen fermentation and methane production in vitro. Rice straw was ammoniated by adding $2 \%$ urea. Rice straw, ammoniated rice straw, $P$. falcataria leaves and S. rarak fruits were oven-dried and finely ground. Experimental treatments were arranged as follow: rice straw (T1), ammoniated rice straw (T2), T2 80\% + P. falcataria 20\% (T3), T2 60\% + $P$. falcataria $40 \%$ (T4), T2 $80 \%+P$. falcataria $10 \%+S$. rarak $10 \%$ (T5), and T2 $60 \%+P$. falcataria $20 \%+$ S. rarak $20 \%$ (T6). An amount of $1 \mathrm{~g}$ sample from each treatment was added with $100 \mathrm{ml}$ rumen fluid and buffer mixture $(1: 2 \mathrm{v} / \mathrm{v})$, and incubated in a water bath at $39^{\circ} \mathrm{C}$ for $48 \mathrm{~h}$. The incubation was performed in four replicates and each replicate was represented by four incubation bottles. Results showed that urea treatment increased gas production of rice straw at 24 and $48 \mathrm{~h}$, higher ammonia production, higher IVDMD, and lower methane production as compared to the untreated rice straw $(\mathrm{P}<0.05)$. Addition of $P$. falcataria or $S$. rarak at lower level produced similar ammonia concentration as ammoniated rice straw whereas their addition at higher level decreased ammonia concentration $(\mathrm{P}<0.05)$. Paraserianthes falcataria addition to ammoniated rice straw decreased protozoa population $(\mathrm{P}<0.05)$ and $S$. rarak further decreased the fauna population $(\mathrm{P}<0.05)$ as well. Inclusion of $S$. rarak at $20 \%$ DM $(T 6)$ produced the lowest methane production both at 24 and $48 \mathrm{~h}$ after incubation and lowest methane production per unit of DM degraded. It was concluded that ammoniation of rice straw improved its nutritional quality with lower methane production, and its mixture with $P$. falcataria and $S$. rarak further increased the quality and lower the production of methane, respectively.
\end{abstract}

(Key words: Ammoniation, In vitro rumen, Paraserianthes falcataria, Sapindus rarak, Rice straw)

\section{INTISARI}

Penelitian ini bertujuan untuk mengamati pengaruh amoniasi jerami padi dan suplementasi sengon laut (Paraserianthes falcataria) dan lerak (Sapindus rarak) terhadap fermentasi rumen dan produksi gas metana secara in vitro. Jerami padi diamoniasi dengan menambahkan urea sebanyak $2 \%$. Jerami padi, jerami padi amoniasi, daun $P$. falcataria dan buah S. rarak dikeringkan menggunakan oven dan digiling halus. Perlakuan yang dilakukan adalah sebagai berikut: jerami padi tanpa amoniasi (T1), jerami padi amoniasi (T2), perlakuan T2 sebanyak $80 \%$ ditambah P. falcataria 20\% (T3), perlakuan T2 sebanyak $60 \%$ ditambah P. falcataria 40\% (T4), perlakuan T2 sebanyak $80 \%$ ditambah P. falcataria sebanyak $10 \%$ dan S. rarak $10 \%$ (T5), dan perlakuan T2 sebanyak $60 \%$ ditambah $P$. falcataria $20 \%$ dan S. rarak $20 \%$ (T6). Sebanyak $1 \mathrm{~g}$ sampel dari masing-masing perlakuan ditambahkan $100 \mathrm{ml}$ cairan rumen:buffer (1:2 v/v), dan diinkubasi di dalam penangas air pada suhu $39^{\circ} \mathrm{C}$ selama 48 jam. Inkubasi dilakukan dalam empat ulangan dan masing-masing ulangan terdiri dari empat botol inkubasi. Hasil penelitian menunjukkan bahwa perlakuan urea meningkatkan produksi gas pada fermentasi rumen jerami padi pada jam ke 24 dan 48, menghasilan produksi amonia lebih tinggi, menunjukkan nilai degradasi bahan kering lebih tinggi, dan produksi metana lebih rendah dibandingkan dengan jerami padi yang tidak diamoniasi $(P<0,05)$. Penambahan $P$. falcataria atau S. rarak pada level rendah menghasilkan konsentrasi amonia yang sama

\footnotetext{
${ }^{*}$ Korespondensi (corresponding author):

Telp. +62 8571092 3501, E-mail: anuraga.jayanegara@gmail.com
} 
dengan jerami padi amoniasi sedangkan penambahan $P$. falcataria atau S. rarak pada level yang lebih tinggi menurunkan konsentrasi amonia $(P<0,05)$. Penambahan $P$. falcataria pada jerami padi amoniasi menurunkan populasi protozoa $(P<0,05)$ dan penambahan $S$. rarak menurunkan populasi protozoa lebih rendah $(P<0,05)$. Penambahan $S$. rarak pada $20 \%$ BK (T6) menghasilkan produksi metana paling rendah pada jam ke 24 dan 48 setelah inkubasi dan juga menghasilkan produksi metana per unit BK terdegradasi yang paling rendah dibandingkan perlakuan lainnya. Penelitian ini dapat disimpulkan bahwa amoniasi jerami padi meningkatkan kualitas nutrisinya sekaligus menurunkan produksi metana, serta penambahan campuran $P$. falcataria dan S. rarak dapat lebih meningkatkan kualitas jerami dan menurunkan produksi metana.

(Kata kunci: Amoniasi, In vitro rumen, Jerami padi, Lerak, Sengon laut)

\section{Introduction}

Rice straw is a common roughage consumed by ruminant in Indonesia particularly in traditional and small-scale farms. The by-product is abundantly available in the country due to the following reasons: (1) rice is a main carbohydrate-rich food consumed by Indonesians, (2) paddy rice cultivation dominates land use for agricultural crop production (Tsujino et al., 2016), and (3) limited utilization of rice straw by farmers especially for those who have no livestock; burning of the straw is unfortunately widely practiced and thus contributes to zero economical value. Although it is produced in high quantity, nutritional quality of rice straw has been known to be low. Rice straw is characterized by high fiber content particularly lignocellulose and high in silica, in which these fractions are negatively correlated with digestibility and animal performance (Sarnklong et al., 2010). Further, rice straw also contains low amount of protein. In the context of environmental protection concern, such fiber-rich feed like rice straw is not favourable due to the high methane emission when the material is entering the rumen and fermented by various anaerobic microorganisms including Archaea methanogens (Soder et al., 2016).

Technology of ammoniation, either by using anhydrous ammonia or urea, has been widely applied to improve nutritional quality of rice straw. It had been shown that application of such technique decreased fiber content of rice straw (Fang et al., 2012), increased its digestibility and improved animal performance (Gunun et al., 2013). However, effect of rice straw ammoniation on methane production is limitedly investigated to date. Another strategy to improve nutritional quality of rice straw is to mix the material with certain feed that high in protein and low in fiber; such characteristics are generally found in legumes. Consuming only rice straw or other agricultural residues cannot meet protein requirement of ruminants and therefore supplementation with a high protein feedstuff is important. A number of forages rich in protein have been used as protein supplements in the diets for ruminant livestock in Indonesia such as Moringa leaves (Jayanegara et al., 2010), katu leaves (Marwah et al., 2010) and cassava leaves (Sudarman et al., 2016). Paraserianthes falcataria (synonym: Albizia falcataria, Falcataria moluccana) or known as sengon laut is a legume tree species with considerable amount of protein content (Akkasaeng et al., 1989; Merkel et al., 1999). Therefore this forage legume is potential to be used for alleviating protein deficiency in rice straw.

High methane production of rice straw when being fermented in the rumen may be overcome by adding certain feed or plant material that rich in plant secondary compounds such as essential oil, tannin and saponin (Jayanegara et al., 2013; 2015; Pirondini et al., 2015). Such enteric methane emission contributes to global warming since the gas is a greenhouse gas. Methane is the second biggest greenhouse gas accumulated in the atmosphere but its capacity to retain heat is 28 times greater than that of carbon dioxide at 100 years period (Tian et al., 2016). An Indonesian plant that rich in saponin content is Sapindus rarak or locally known as lerak, particularly in its fruit (Suharti et al., 2009; Yuliana et al., 2014). Thus S. rarak fruit may be combined with rice straw in order to reduce its effect on methane production. Together with urea treatment and $P$. falcataria leaf supplementation, it is expected that all these strategies may simultaneously improve nutritional quality and reduce methane production of rice straw. The present study aimed to observe the 
effects of rice straw ammoniation and supplementation of $P$. falcataria and $S$. rarak on rumen fermentation and methane production by in vitro analysis.

\section{Materials and Methods}

\section{Sample preparation}

Rice straw was collected from paddy rice field in Purwokerto. The material was ammoniated by adding $2 \%$ of urea (dry matter basis) and kept for two weeks incubation. Paraserianthes falcataria leaves were freshly collected from Agrostology Experimental Field, Bogor Agricultural University. Sapindus rarak fruits were purchased from Pasar Anyar traditional market in Bogor. These materials were ovendried at $60^{\circ} \mathrm{C}$ for $24 \mathrm{~h}$, ground with a hammer mill to pass a $1 \mathrm{~mm}$ sieve and used in further experimental steps.

\section{Chemical composition analysis}

Ground samples of rice straw (nonammoniated and ammoniated), Paraserianthes falcataria leaves and Sapindus rarak fruits were analyzed for dry matter (DM), organic matter (OM), ash, crude protein (CP) and ether extract (EE) contents (AOAC, 2005). Neutral detergent fiber (NDF), acid detergent fiber (ADF) and lignin contents were determined by following the procedures of Van Soest et al. (1991). Hemicellulose and cellulose contents were obtained by difference between NDF and ADF and between ADF and lignin, respectively. Analyses of tannin and saponins contents were performed according to Makkar et al. (2007). All chemical composition analyses were conducted in duplicate.

\section{In vitro analysis}

Samples of unammoniated and ammoniated rice straw, Paraserianthes falcataria and Sapindus rarak were arranged and mixed according to the following experimental treatments (dry matter basis):

T1 : Rice straw

T2 : Ammoniated rice straw

T3 : T2 $80 \%+P$. falcataria $20 \%$

T4 : T2 60\% + P. falcataria $40 \%$

T5 : T2 $80 \%+$ P. falcataria $10 \%+$ S. rarak $10 \%$

T6 : T2 $60 \%+P$. falcataria $20 \%+S$. rarak $20 \%$
These treatments were subjected to in vitro analysis according to Theodorou et al. (1994). An amount of $1 \mathrm{~g}$ sample from each treatment was inserted into a $125 \mathrm{ml}$ serum bottle, followed by addition of $100 \mathrm{ml}$ rumen fluid:buffer mixture (1:2 v/v). Rumen fluid was obtained from a fistulated Friesian Holstein crossbred cow before morning feeding. The cow was fed with napier grass and commercial concentrate (60:40 w/w). Buffer solution was prepared by mixing $9.8 \mathrm{~g}$ $\mathrm{NaHCO}_{3}, 3.71 \mathrm{~g} \mathrm{Na} \mathrm{HPO}_{4} .7 \mathrm{H}_{2} \mathrm{O}, 0.57 \mathrm{~g} \mathrm{KCl}$, $0.47 \mathrm{~g} \mathrm{NaCl}, 0.12 \mathrm{~g} \mathrm{MgSO}_{4} .7 \mathrm{H}_{2} \mathrm{O}$ and $0.04 \mathrm{~g}$ $\mathrm{CaCl}_{2}$ in $1000 \mathrm{ml}$ distilled water. Anaerobic condition of the in vitro system was maintained by continuous gassing of the incubation medium with $\mathrm{CO}_{2}$ gas. Serum bottles were sealed with butyl rubber stoppers and aluminum crimp seals shortly before starting the incubation. The bottles were placed in a water bath at $39^{\circ} \mathrm{C}$ for $48 \mathrm{~h}$. At $3,6,9,12,24$ and $48 \mathrm{~h}$ after the start of the in vitro incubation, gas production from each serum bottle was vented and recorded. The incubation was performed in four runs (replicates) and each treatment per run was represented by four incubation bottles.

\section{Post-incubation measurement}

Methane production was measured at 24 and $48 \mathrm{~h}$ after incubation by following the procedure of Yuliana et al. (2014). At the end of incubation, liquid samples were withdrawn for volatile fatty acid (VFA), ammonia $\left(\mathrm{NH}_{3}\right)$, total bacteria and protozoa determinations. Concentration of VFA was determined by using a gas chromatograph (GC 8A, Shimadzu Corp., Kyoto, Japan) with a column containing 10\% SP-1200, $1 \% \mathrm{H}_{3} \mathrm{PO}_{4}$ on 80/100 Cromosorb WAW. Chromatogram of VFA sample was compared with known concentration of VFA standard (acetate, propionate and butyrate). Ammonia concentration was measured by using Conway micro-diffusion technique. Total bacteria and protozoa population were enumerated by using roll tube and counting chamber methods, respectively. Solid residues after incubation were determined for dy matter contents and used to determine dry matter degradability (DMD).

\section{Calculation and data analysis}

Chemical compositions of mixtures between ammoniated rice straw, $P$. falcataria 
and $S$. rarak at various proportions were calculated from their individual compositions. Data on in vitro incubation, i.e. gas production, rumen fermentation and methane production were analyzed by analysis of variance (ANOVA) by following a randomixed complete block design. Different batch of rumen fluid sampling at different experimental run served as the block in ANOVA. Outliers were detected through standardized residuals in which their values were lower than -3 or higher than 3 , and subsequently were removed from the dataset. Comparison among different treatments was performed by applying Duncan's multiple range test. All the statistical analyses were performed by using SPSS software version 20.0.

\section{Results and Discussion}

\section{Chemical composition}

Paraserianthes falcataria leaves contained a relatively high $\mathrm{CP}$ content, i.e. above $15 \%$ DM, whereas CP content of $S$. rarak fruits was approximately half of $P$. falcataria (Table 1). Both plants had low EE contents. Much higher NDF and ADF were observed in $P$. falcataria than those of $S$. rarak; both contained negligible amounts of lignin. Paraserianthes falcataria and $S$. rarak contained considerable amounts of plant secondary metabolites, i.e. tannin and saponin, respectively. Content of CP was low in rice straw ( $\mathrm{T} 1)$, and urea treatment (T2) increased substantially the CP content (Table 2). In comparison to $P$. falcataria, NDF and ADF contents of rice straw were higher by 46.5 and $20.6 \%$, respectively. Urea treatment decreased NDF, ADF and lignin contents of rice straw by $15.1,11.8$ and $5.0 \%$, respectively. Addition of $P$. falcataria to ammoniated rice straw (T3 and T4) increased its CP and tannin contents, and decreased its NDF, ADF and lignin contents. Addition of $S$. rarak to ammoniated rice straw and $P$. falcataria mixture (T5 and T6) further decreased its NDF and ADF contents, and added a certain amount of saponin.

The CP content of $P$. falcataria in this study was slightly lower than that of reported by Akkasaeng et al. (1989); the authors reported that the species contained 18.6 and $19.5 \%$ CP (DM basis), obtained at two different collection periods. Merkel et al. (1999) even reported a higher value of CP in $P$. falcataria, i.e. $21.3 \% \mathrm{DM}$, and used the plant as a protein supplement (fed up to $50 \%$ of dietary $\mathrm{CP}$ ) for growing lambs. The NDF values of $P$. falcataria reported in literatures ranged from 40.7 to $51.1 \%$ DM (Akkasaeng et al., 1989; Merkel et al., 1999); these were lower than what was observed in the present study. It seems that $P$. falcataria used in this study is of lower quality than the literatures as shown by the lower CP and higher NDF values, most probably due to older age of the plant sampled. As a forage gets more mature, cell wall proportion increases, and thus elevate its fiber proportion on one side and decrease its protein proportion on the other side. Moderate level of tannin present in $P$. falcataria was also reported in other studies. D'Mello (1992), for instance, reported that $P$. falcataria contained $4.7 \%$ condensed tannin. Further, Jayanegara et al. (2011) reported that the plant contained 6.4\% tannin, in which $4.6 \%$ was in the form of condensed tannin and $1.8 \%$ was hydrolysable tannin.

Content of $\mathrm{CP}$ in $S$. rarak was relatively similar to that of reported by Suharti et al. (2009), i.e. around 7\% DM. The fruit has been well-known to contain considerable amount of saponin (Yogianto et al., 2014; Yuliana et al., 2014). Suharti et al. (2009)

Table 1. Chemical composition of Paraserianthes falcataria and Sapindus rarak (dry matter basis)

\begin{tabular}{lcc}
\hline \hline \multicolumn{1}{c}{ Component } & P. falcataria & S. rarak \\
\hline Organic matter & 94.7 & 97.9 \\
Ash & 5.3 & 2.1 \\
Crude protein & 16.5 & 7.8 \\
Ether extract & 0.8 & 0.7 \\
NDF & 59.6 & 24.0 \\
ADF & 50.1 & 19.4 \\
Lignin & 0.8 & nd \\
Hemicellulose & 9.5 & 4.6 \\
Cellulose & 49.3 & 19.4 \\
Tannin & 3.1 & nd \\
Saponin & nd & 6.9 \\
\hline ADF, acid detgent fibe; nd, not detecte NDF, neutal detergent fiber.
\end{tabular}

ADF, acid detergent fiber; nd, not detected; NDF, neutral detergent fiber. 
Buletin Peternakan Vol. 41 (4): 420-430, November 2017

Bulletin of Animal Science, DOI: 10.21059/buletinpeternak.v41i4.25549

Table 2. Chemical composition of experimental treatments (dry matter basis)

\begin{tabular}{|c|c|c|c|c|c|c|}
\hline Component & $\mathrm{T} 1$ & T2 & T3 & $\mathrm{T} 4$ & T5 & T6 \\
\hline Organic matter & 79.8 & 80.7 & 83.5 & 86.3 & 83.8 & 86.9 \\
\hline Ash & 20.2 & 19.3 & 16.5 & 13.7 & 16.2 & 13.1 \\
\hline Crude protein & 6.5 & 11.7 & 12.7 & 13.6 & 11.8 & 11.9 \\
\hline Ether extract & 0.3 & 1.1 & 1.0 & 1.0 & 1.0 & 1.0 \\
\hline NDF & 87.3 & 74.1 & 71.2 & 68.3 & 67.6 & 61.2 \\
\hline ADF & 60.4 & 53.3 & 52.7 & 52.0 & 49.6 & 45.9 \\
\hline Lignin & 15.9 & 15.1 & 12.2 & 9.4 & 12.2 & 9.2 \\
\hline Hemicellulose & 26.9 & 20.8 & 18.5 & 16.3 & 18.1 & 15.3 \\
\hline Cellulose & 44.5 & 38.2 & 40.4 & 42.6 & 37.4 & 36.7 \\
\hline Tannin & nd & nd & 0.6 & 1.2 & 0.3 & 0.6 \\
\hline Saponin & nd & nd & nd & nd & 0.7 & 1.4 \\
\hline
\end{tabular}

T1: rice straw; T2: ammoniated rice straw; T3: T2 80\% + P. falcataria 20\%; T4: T2 60\% + P. falcataria 40\%; T5: T2 $80 \%+P$. falcataria $10 \%+$ S. rarak $10 \%$; T6: T2 60\% + P. falcataria $20 \%+$ S. rarak $20 \%$.

ADF: acid detergent fiber; nd: not detected; NDF: neutral detergent fiber.

observed that saponin content of S. Rarak meal was $3.87 \% \mathrm{DM}$; this was lower in comparison to our result. Other species of sapindus such as Sapindus saponaria and Sapindus mukorossi also contain significant concentration of saponin (Kamra et al., 2008; Soliva et al., 2008; Delgado et al., 2012). Due to its low CP but high saponin contents, $S$. rarak is often used as an extracted form rather than its intact form.

Lower NDF and ADF in urea-treated rice straw in comparison to that of the untreated was expected. Urea may be used for ammoniation technique of high-fiber materials since it is converted to ammonia after dissolved in water and by the action of urease enzyme. Ammonia released is absorbed into cell wall, cleaves lignocellulose component, and converts it into lignin, cellulose and some other smaller molecules (Sarnklong et al., 2010). Other authors also reported a decrease in fiber content of rice straw after applying urea treatment (Vadiveloo and Fadel, 2009; Fang et al., 2012; Gunun et al., 2013). Fiber-decreasing effect of urea treatment does not only apply to rice straw but also to other materials or byproducts rich in fiber. Laconi and Jayanegara (2015), for instance, reported that urea treatment of cocoa pod (1.5\% addition level) decreased crude fiber and ADF contents by 8.6 and $11.8 \%$, respectively. Another advantage of using urea, apart from its ability to break down lignocellulose, is that the compound supplies nitrogen and can further be converted into microbial protein (Gunun et al., 2016). Increasing concentration of CP observed in ammoniated rice straw in this study was clearly a contribution from urea as a source of non-protein nitrogen.

\section{Rumen fermentation}

All treatments produced similar gas production up to $12 \mathrm{~h}$ after incubation (Table 3 ). Urea treatment increased gas production of rice straw by 18.9 and $20.2 \%$ at 24 and 48 $\mathrm{h}$ of in vitro analysis, respectively $(\mathrm{P}<0.05)$. Addition of $P$. falcataria to ammoniated rice straw at 20 and $40 \%$ DM did not further improved gas production. Addition of $S$. rarak to ammoniated rice straw and $P$. falcataria mixture at different levels resulted in a different response; addition at $10 \% \mathrm{DM}$ produced similar gas production whereas at $20 \%$ DM decreased gas production $(P<0.05)$ as compared to $\mathrm{T} 3$ and $\mathrm{T} 4$, respectively. Urea treatment and addition of $P$. falcataria and/or $S$. rarak did not change total VFA production and molar proportion of individual VFA of rice straw during $24 \mathrm{~h}$ in vitro incubation (Table 4). Rice straw treated with urea had higher ammonia concentration by $72 \%$ than that of the untreated rice straw $(\mathrm{P}<0.05)$. Addition of $P$. falcataria or $S$. rarak at lower level produced similar ammonia concentration as ammoniated rice straw whereas their addition at higher level decreased ammonia concentration $(P<0.05)$. Ammoniation of rice straw increased its degradability by $37.1 \% \quad(\mathrm{P}<0.05$; Table 5$)$. Addition of both $P$. falcataria and/or $S$. rarak did not further increase the degradability of ammoniated rice straw. Dietary treatments showed indifferent total bacteria population but, on the contrary, revealed different protozoa population. Paraserianthes falcataria addition to ammoniated rice straw decreased the protozoa population $(P<0.05)$ and $S$. rarak further decreased the fauna population $(P<0.05)$. 
Table 3. Gas production kinetics of experimental treatments

\begin{tabular}{lllllll}
\hline \hline Treatment & \multicolumn{7}{c}{ Gas production $(\mathrm{ml} / \mathrm{g})$} \\
\cline { 2 - 6 } & $3 \mathrm{~h}$ & $6 \mathrm{~h}$ & $9 \mathrm{~h}$ & $12 \mathrm{~h}$ & $24 \mathrm{~h}$ & $48 \mathrm{~h}$ \\
\hline T1 & 5.3 & 10.5 & 16.0 & 20.5 & $45.6^{\mathrm{a}}$ & $77.4^{\mathrm{a}}$ \\
T2 & 5.8 & 9.7 & 14.8 & 22.3 & $54.2^{\mathrm{b}}$ & $93.0^{\mathrm{b}}$ \\
T3 & 5.8 & 10.1 & 14.9 & 22.6 & $57.8^{\mathrm{b}}$ & $92.3^{\mathrm{b}}$ \\
T4 & 7.5 & 12.4 & 17.3 & 23.4 & $53.7^{\mathrm{b}}$ & $86.9^{\mathrm{b}}$ \\
T5 & 6.3 & 11.4 & 17.3 & 23.6 & $54.1^{\mathrm{b}}$ & $91.1^{\mathrm{b}}$ \\
T6 & 4.7 & 9.1 & 14.4 & 18.9 & $44.2^{\mathrm{a}}$ & $75.8^{\mathrm{a}}$ \\
SEM & 0.42 & 0.53 & 0.64 & 0.81 & 1.21 & 1.64 \\
P-value & 0.109 & 0.093 & 0.214 & 0.075 & $<0.001$ & $<0.001$ \\
\hline
\end{tabular}

${ }_{a, b}$ Different superscripts within the same column are significantly different at $\mathrm{P}<0.05$.

T1: rice straw; T2: ammoniated rice straw; T3: T2 80\% + P. falcataria 20\%; T4: T2 60\% + P. falcataria 40\%; T5: T2 $80 \%+P$. falcataria $10 \%+$ S. rarak $10 \% ;$ T6: T2 $60 \%+P$. falcataria $20 \%+$ S. rarak $20 \%$. SEM: standard error of mean.

Table 4. Rumen fermentation of experimental treatments

\begin{tabular}{lccccc}
\hline \hline Treatment & Total VFA $(\mathrm{mmol} / \mathrm{l})$ & $\mathrm{C}_{2}(\%)$ & $\mathrm{C}_{3}(\%)$ & $\mathrm{C}_{4}(\%)$ & $\mathrm{NH}_{3}(\mathrm{mmol} / \mathrm{l})$ \\
\hline T1 & 63.9 & 62.1 & 25.6 & 12.3 & $15.4^{\mathrm{a}}$ \\
T2 & 57.1 & 65.2 & 23.8 & 11.0 & $26.5^{\mathrm{c}}$ \\
T3 & 74.3 & 60.0 & 27.4 & 12.6 & $26.5^{\mathrm{c}}$ \\
T4 & 67.8 & 54.8 & 26.3 & 18.9 & $20.3^{\mathrm{b}}$ \\
T5 & 59.1 & 64.3 & 24.6 & 11.1 & $24.6^{\mathrm{c}}$ \\
T6 & 62.5 & 60.0 & 25.1 & 15.0 & $20.7^{\mathrm{b}}$ \\
SEM & 3.98 & 1.58 & 1.02 & 0.96 & 0.87 \\
P-value & 0.597 & 0.220 & 0.920 & 0.071 & $<0.001$ \\
\hline
\end{tabular}

$\overline{a, b, c}$ Different superscripts within the same column are significantly different at $\mathrm{P}<0.05$.

T1: rice straw; T2: ammoniated rice straw; T3: T2 80\% + P. falcataria 20\%; T4: T2 60\% + P. falcataria 40\%; T5: T2 $80 \%+P$. falcataria $10 \%+$ S. rarak $10 \% ;$ T6: T2 60\% + P. falcataria $20 \%+$ S. rarak $20 \%$.

$\mathrm{C}_{2}$, acetate; $\mathrm{C}_{3}$, propionate; $\mathrm{C}_{4}$, butyrate; $\mathrm{NH}_{3}$, ammonia; SEM, standard error of mean; VFA, volatile fatty acid.

Table 5. Degradability and microbial population of experimental treatments

\begin{tabular}{|c|c|c|c|}
\hline Treatment & IVDMD (\%) & Bacteria $\left(10^{9} / \mathrm{ml}\right)$ & Protozoa $\left(10^{5} / \mathrm{ml}\right)$ \\
\hline T1 & $34.5^{\mathrm{a}}$ & 4.10 & $12.38^{c}$ \\
\hline T2 & $47.3^{\mathrm{c}}$ & 6.29 & $10.13^{c}$ \\
\hline T3 & $47.3^{\mathrm{c}}$ & 5.17 & $8.25^{b}$ \\
\hline T4 & $42.5^{\mathrm{b}}$ & 4.35 & $8.63^{b}$ \\
\hline T5 & $42.0^{\mathrm{b}}$ & 4.27 & $5.63^{\mathrm{a}}$ \\
\hline T6 & $41.1^{\mathrm{b}}$ & 4.82 & $4.25^{\mathrm{a}}$ \\
\hline SEM & 0.86 & 0.46 & 0.06 \\
\hline P-value & $<0.001$ & 0.182 & $<0.001$ \\
\hline
\end{tabular}

a,b,c Different superscripts within the same column are significantly different at $\mathrm{P}<0.05$.

T1: rice straw; T2: ammoniated rice straw; T3: T2 80\% + P. falcataria 20\%; T4: T2 60\% + P. falcataria 40\%; T5: T2 $80 \%+P$. falcataria $10 \%+$ S. rarak $10 \% ;$ T6: T2 60\% + P. falcataria $20 \%+$ S. rarak $20 \%$.

IVDMD: in vitro dry matter degradability; SEM: standard error of mean.

Cell wall expansion and degradation of rice straw due to urea treatment enables rumen microbes to attack, colonize and degrade the fiber component more easily. It was confirmed by the increase of gas production and degradability of ammoniated rice straw in comparison to the untreated rice straw. Gas produced in an in vitro rumen fermentation system is originated from two sources; it is an end product of microbial metabolism during feed degradation and fermentation, and as a result of VFA buffering process by bicarbonate buffer present in the incubation medium (Jayanegara et al., 2017). Therefore gas production is considered as an indicator of feed degradability or digestibility. A number of studies have shown a positive correlation between gas production and feed digestibility (Sebata et al., 2011; Plaizier and Li, 2013). An increase of rumen ammonia concentration in the incubation of ureatreated rice straw indicates that the urea is converted to ammonia and further solubilized in the rumen. With regard to VFA produced, in contrast to our expectation, total VFA and its individual components did not change by urea treatment. Generally an increase of gas production is accompanied by an increase of total VFA concentration since both 
parameters are end products of metabolism of rumen microbes, particularly from carbohydrate metabolism (Morvay et al., 2011; Jayanegara et al., 2017). Apparently the insignificancy of total and individual VFA in the present study is due to the high variation among replicates.

Supplementation of $P$. falcataria at $40 \%$ DM decreased in vitro DM degradability and ammonia concentration apparently was due to tannin present in the plant. Tannin has the ability to form complexes with macromolecules such as protein and carbohydrate particularly via its multiple hydroxyl groups, making the nutrients less available for rumen microbial degradation (Piluzza et al., 2014) and hence less degradability. Through such complex formation, stepwise protein degradation to peptides and amino acids, and subsequent deamination to form ammonia is hampered; this was confirmed by the lower rumen ammonia concentration at $40 \%$ DM $P$. falcataria supplementation, in which the mixed diet contained $1.2 \%$ tannin. In agreement with the current finding, in a metaanalysis study, it was shown that higher concentration of condensed tannin in diet led to a lower rumen ammonia and isoVFA concentrations both in in vitro and in vivo experiments (Jayanegara and Palupi, 2010). Jolazadeh et al. (2015) also observed that tannin (extracted from pistachio hulls) treatment of soybean meal lowered its proportion of rumen degradable protein and increased proportion of rumen undegradable protein. Lower protozoa population due to $P$. falcataria supplementation was apparently related to defaunation activity of tannin as also observed by other authors (Bhatta et al., 2009).

The decrease of protozoa population by addition of $S$. rarak indicates that saponin has a defaunation activity against the fauna. Saponin forms a complex with cholesterol in the cell membrane of protozoa, changes its permeability and induces cell lysis (Jayanegara et al., 2014). Supporting the present finding, studies performed by other authors also demonstrated a decrease of protozoa population by addition of saponin (Zhou et al., 2011; Ramos-Morales et al., 2017). A meta-analysis study of Jayanegara et al. (2014) revealed that all saponin sources evaluated, i.e. quillaja, tea and yucca saponins had the ability to reduce protozoa population in the rumen with relatively similar magnitude of reduction among the sources. With regard to ammonia decreasing effect of saponin in $S$. rarak, it is apparently related to the following mechanisms: (1) sugar component of saponin interacts with ammonia, making the ammonia less available, (2) reduction of predation intensity of protozoa on rumen bacteria as a result of anti-protozoal effect of saponin in which such predation leads to microbial protein degradation to form ammonia; when the predation intensity is reduced then formation of ammonia is reduced as well, and (3) saponin inhibits the growth of some rumen microbes that degrade protein to amino acids and ammonia such as Butyrivibrio fibrisolvens, Streptococcus bovis and Prevotella bryantii (Patra and Saxena, 2009; Jayanegara et al., 2014).

\section{Methane production}

Inclusion of S. rarak at $20 \%$ DM (T6) produced the lowest methane production both at 24 and $48 \mathrm{~h}$ after incubation (Table 6). When methane was presented as percentage to total gas, ammoniation of rice straw (T2) resulted in a lower methane concentration than that of untreated rice straw $(\mathrm{T} 1 ; \mathrm{P}<0.05)$; the decrease was 19.7 and $18.5 \%$ at 24 and $48 \mathrm{~h}$, respectively. Such response was also similar when methane was expressed as a proportion to degradable DM with a higher magnitude of decrease, i.e. $29.0 \%$. Methane production per unit of DM degraded was lowest at the highest $S$. rarak inclusion level (T6). Addition of $P$. falcataria lowered methane production at $48 \mathrm{~h}$ incubation in comparison to ammoniated rice straw $(P<0.05)$, but it was non-significant for methane concentration and methane per unit of DM degraded.

The decrease of methane percentage to total gas and methane per unit of degradable DM in ammoniated rice straw incubation was apparently related to the change of carbohydrate fractions after urea treatment. Urea treatment decreased NDF and ADF contents of rice straw and converted them to more readily available carbohydrate as discussed above. Such cell wall fractions are positively correlated with methane production since fiber degradation by rumen microbes produce large amount of hydrogen that acts as a main substrate for methanogenesis (Jayanegara et al., 2011). The present result indicates that urea 
Table 6. Methane $\left(\mathrm{CH}_{4}\right)$ production of experimental treatments

\begin{tabular}{|c|c|c|c|c|c|}
\hline \multirow[t]{2}{*}{ Treatment } & \multicolumn{2}{|c|}{$\mathrm{CH}_{4}(\mathrm{ml} / \mathrm{g})$} & \multicolumn{2}{|c|}{$\mathrm{CH}_{4}$ (\%gas) } & \multirow[t]{2}{*}{$\mathrm{CH}_{4} / \mathrm{IVDMD}(\mathrm{ml} / \mathrm{g})$} \\
\hline & $24 \mathrm{~h}$ & $48 \mathrm{~h}$ & $24 \mathrm{~h}$ & $48 \mathrm{~h}$ & \\
\hline T1 & $12.0^{\mathrm{b}}$ & $19.1^{\mathrm{C}}$ & $25.4^{\mathrm{b}}$ & $23.3^{c}$ & $54.1^{c}$ \\
\hline T2 & $11.6^{b}$ & $18.6^{c}$ & $20.4^{a}$ & $19.0^{a}$ & $38.4^{\mathrm{ab}}$ \\
\hline T3 & $11.7^{\mathrm{b}}$ & $17.9^{b c}$ & $19.5^{a}$ & $18.8^{a}$ & $37.6^{a}$ \\
\hline T4 & $11.0^{\mathrm{b}}$ & $16.4^{\mathrm{b}}$ & $20.2^{\mathrm{a}}$ & $18.6^{a}$ & $38.5^{\mathrm{ab}}$ \\
\hline T5 & $11.7^{\mathrm{b}}$ & $19.6^{c}$ & $21.2^{\mathrm{a}}$ & $20.9^{b}$ & $43.8^{\mathrm{b}}$ \\
\hline T6 & $8.4^{\mathrm{a}}$ & $14.5^{\mathrm{a}}$ & $19.4^{a}$ & $19.5^{\mathrm{ab}}$ & $34.1^{\mathrm{a}}$ \\
\hline SEM & 0.54 & 0.79 & 0.90 & 0.80 & 2.00 \\
\hline$P$-value & $<0.001$ & $<0.001$ & $<0.001$ & $<0.001$ & $<0.001$ \\
\hline
\end{tabular}

a,b,c Different superscripts within the same column are significantly different at $\mathrm{P}<0.05$

T1: rice straw; T2: ammoniated rice straw; T3: T2 80\% + P. falcataria 20\%; T4: T2 60\% + P. falcataria 40\%; T5: T2 $80 \%+P$. falcataria $10 \%+$ S. rarak $10 \%$; T6: T2 60\% + P. falcataria $20 \%+$ S. rarak $20 \%$.

IVDMD: in vitro dry matter degradability; SEM: standard error of mean.

treatment of rice straw does not only improve its nutritive value but also beneficial with regard to decreasing environmental emission. Supporting this result, increasing forage to concentrate ratio from 47:53 (lower fiber diet) to 68:32 (higher fiber diet) increased methane emission of dairy cows from 538 to $648 \mathrm{~g} /$ day (Aguerre et al., 2011). More recently, Adejoro and Hassen (2017) supplemented or treated Eragrostis curvula hay with urea and observed the effects of such experimental treatments on digestibility and in vitro fermentation. The authors reported that hay treated with urea resulted in lower methane production, methane to total gas and methane per unit OM digested in comparison to the control hay. Urea treatment also increased total gas production, in vitro OM digestibility, and total VFA production of the hay, but no change of individual VFA proportion (acetate, propionate, butyrate and acetate-topropionate molar ratio) was observed.

Methane reduction effect of $S$. rarak supplementation at $20 \%$ DM (T6) was evident. Supplementation of the fruit at $10 \%$ DM (T5) was not significant apparently because of the lower level of saponin present in the mixed diet, i.e. $0.7 \% \mathrm{DM}$, whereas saponin content in T6 diet was $1.4 \%$ DM. Such methane decrease by saponin seems to be related with its defaunation activity against rumen protozoa. Certain population of archaea methanogen live in symbiosis with protozoa in which they take advantage from the fauna by consuming the hydrogen released and use it as a primary substrate for methanogenesis (Morgavi et al., 2010). Therefore in the presence of saponin, it is expected that methanogen population is reduced as well. Accordingly, Goel et al. (2008) demonstrated that addition of saponin-rich fractions from carduus (Carduus pycnocephalus), sesbania (Sesbania sesban), knautia (Knautia arvensis) or fenugreek (Trigonella foenum-graecum) into hay:concentrate diet $(1: 1 \mathrm{w} / \mathrm{w})$ decreased both protozoal numbers and methanogen relative abundance. A study of Narvaez et al. (2013) showed that supplementation of Yucca schidigera extract (containing 153 $\mathrm{mg} / \mathrm{g}$ DM steroidal sapogenin) at a level of $650 \mu \mathrm{g} / \mathrm{ml}$ decreased methanogenic archaea population from $247.8 \times 10^{8}$ to $118.3 \times 10^{8}$ gene copies. In addition to such population decrease, saponin might also reduce the activity of methanogenic archaea. Another plausible explanation of the lower methane production due to saponin is that the compound had been demonstrated to inhibit cellulolytic bacteria and anaerobic fungi in which both microbial groups are responsible for fiber degradation in the rumen (Guo et al., 2008). Such inhibition may lead to further reduction of hydrogen provision for methane formation.

\section{Conclusion}

Urea treatment of rice straw effectively improves its nutritive value as indicated by the lower NDF and ADF contents, higher gas production, rumen ammonia concentration and in vitro DM degradability. Further, such treatment provide an additional advantage by lowering enteric methane production, a major greenhouse gas in the atmosphere contributing to global warming. Supplementation of $P$. falcataria to ammoniated rice straw may provide further benefit with regard to higher protein content and a shift toward more proportion of rumen undegradable protein due to its tannin content. Although supplementation of $S$. rarak does not improve nutritional quality of ammoniated and $P$. falcataria mixture, it may 
strategically be used to further lower the methane production since the plant is rich in saponin.

\section{Acknowledgement}

This research was funded by Indonesian Ministry of Research, Technology and Higher Education through "Penelitian Fundamental' research grant.

\section{References}

Adejoro, F. A. and A. Hassen. 2017. Effect of supplementing or treating Eragrostis curvula hay with urea or nitrate on its digestibility and in vitro fermentation. S. Afr. J. Anim. Sci. 47: 168-177.

Aguerre, M. J., M. A. Wattiaux, J. M. Powell, G. A. Broderick and C. Arndt. 2011. Effect of forage-to-concentrate ratio in dairy cow diets on emission of methane, carbon dioxide, and ammonia, lactation performance, and manure excretion. J. Dairy Sci. 94: 3081-3093.

Akkasaeng, R., R. C. Gutteridge and M. Wanapat. 1989. Evaluation of trees and shrubs for forage and fuel wood in Northeast Thailand. Int. Tree Crops J. 5: 209-220.

AOAC. 2005. Official Methods of Analysis. $18^{\text {th }}$ edn. AOAC International, Arlington, VA, USA.

Bhatta, R., Y. Uyeno, K. Tajima, A. Takenaka, Y. Yabumoto, I. Nonaka, O. Enishi and M. Kurihara. 2009. Difference in the nature of tannins on in vitro ruminal methane and volatile fatty acid production and on methanogenic archaea and protozoal populations. J. Dairy Sci. 92: 55125522.

Delgado, D. C., J. Galindo, R. Gonzalez, N. Gonzalez, I. Scull, L. Dihigo, J. Cairo, A. I. Aldama and O. Moreira. 2012. Feeding of tropical trees and shrub foliages as a strategy to reduce ruminal methanogenesis: Studies conducted in Cuba. Trop. Anim. Health Prod. 44: 1097-1104.

D'Mello, J. P. F. 1992. Chemical constraints to the use of tropical legumes in animal nutrition. Anim. Feed Sci. Technol. 38: 237-261.
Fang, J., M. Matsuzaki, H. Suzuki, Y. Cai, K. I. Horiguchi and T. Takahashi. 2012. Effects of lactic acid bacteria and urea treatment on fermentation quality, digestibility and ruminal fermentation of roll bale rice straw silage in wethers. Grassland Sci. 58: 73-78.

Goel, G., H. P. S. Makkar and K. Becker. 2008. Changes in microbial community structure, methanogenesis and rumen fermentation in response to saponinrich fractions from different plant materials. J. Appl. Microbiol. 105: 770777

Guo, Y.Q., J. X. Liu, Y. Lu, W. Y. Zhu, S. E. Denman and C. S. McSweeney. 2008. Effect of tea saponin on methanogenesis, microbial community structure and expression of mcrA gene, in cultures of rumen microorganisms. Lett. Appl. Microbiol. 47: 421-426.

Gunun, P., M. Wanapat and N. Anantasook. 2013. Effects of physical form and urea treatment of rice straw on rumen fermentation, microbial protein synthesis and nutrient digestibility in dairy steers. Asian Australas. J. Anim. Sci. 26: 1689-1697.

Gunun, N., M. Wanapat, P. Gunun, A. Cherdthong, P. Khejornsart and S. Kang. 2016. Effect of treating sugarcane bagasse with urea and calcium hydroxide on feed intake, digestibility, and rumen fermentation in beef cattle. Trop. Anim. Health Prod. 48: 1123-1128.

Jayanegara, A. and E. Palupi. 2010. Condensed tannin effects on nitrogen digestion in ruminants: A metaanalysis from in vitro and in vivo studies. Media Peternakan 33: 176181.

Jayanegara, A., T. Sabhan, A. K. Takyi, A. O. Salih and E. M. Hoffmann. 2010. Ruminal fermentation kinetics of moringa and peltiphyllum supplements during early incubation period in the in vitro Reading pressure technique. J. Indonesian Trop. Anim. Agric. 35: 165171.

Jayanegara, A., E. Wina, C. R. Soliva, S. Marquardt, M. Kreuzer and F. Leiber. 2011. Dependence of forage quality and methanogenic potential of tropical plants on their phenolic fractions as 
determined by principal component analysis. Anim. Feed Sci. Technol. 163: 231-243.

Jayanegara, A., S. Marquardt, E. Wina, M. Kreuzer and F. Leiber. 2013. In vitro indications for favourable non-additive effects on ruminal methane mitigation between high-phenolic and highquality forages. Br. J. Nutr. 109: 615622.

Jayanegara, A., E. Wina and J. Takahashi. 2014. Meta-analysis on methane mitigating properties of saponin-rich sources in the rumen: Influence of addition levels and plant sources. Asian Australas. J. Anim. Sci. 27: 1426-1435.

Jayanegara, A., G. Goel, H. P. S. Makkar and K. Becker. 2015. Divergence between purified hydrolysable and condensed tannin effects on methane emission, rumen fermentation and microbial population in vitro. Anim. Feed Sci. Technol. 209: 60-68.

Jayanegara, A., Y. C. Sari, R. Ridwan, D. Diapari and E. B. Laconi. 2017. Protein fractionation and utilization of soybean and redbean at different drying temperatures. Bul. Pet. 41: 37-47.

Jolazadeh, A. R., M. Dehghan-Banadaky and K. Rezayazdi. 2015. Effects of soybean meal treated with tannins extracted from pistachio hulls on performance, ruminal fermentation, blood metabolites and nutrient digestion of Holstein bulls. Anim. Feed Sci. Technol. 203: 33-40.

Kamra, D. N., A. K. Patra, P. N. Chatterjee, R. Kumar, N. Agarwal and L. C. Chaudhary. 2008. Effect of plant extracts on methanogenesis and microbial profile of the rumen of buffalo: A brief overview. Aust. J. Exp. Agric. 48: 175-178.

Laconi, E. B. and A. Jayanegara. 2015. Improving nutritional quality of cocoa pod (Theobroma cacao) through chemical and biological treatments for ruminant feeding: in vitro and in vivo evaluation. Asian Australas. J. Anim. Sci. 28: 343-350.

Makkar, H. P. S., P. Siddhuraju and K. Becker. 2007. Plant Secondary Metabolites. Humana Press, Totowa, New Jersey.

Marwah, M. P., Y. Y. Suranindyah, dan T. W. Murti. 2010. Produksi dan komposisi susu kambing Peranakan Ettawa yang diberi suplemen daun katu (Sauropus androgynus (L.) Merr) pada awal masa laktasi. Buletin Peternakan 34: 94-102.

Merkel, R. C., K. R. Pond, J. C. Burns and D. S. Fisher. 1999. Intake, digestibility and nitrogen utilization of three tropical tree legumes. II. As protein supplements. Anim. Feed Sci. Technol. 82: 107-120.

Morgavi, D. P., E. Forano, C. Martin and C. J. Newbold. 2010. Microbial ecosystem and methanogenesis in ruminants. Animal. 4: 1024-1036.

Morvay, Y., A. Bannink, J. France, E. Kebreab and J. Dijkstra. 2011. Evaluation of models to predict the stoichiometry of volatile fatty acid profiles in rumen fluid of lactating Holstein cows. J. Dairy Sci. 94: 30633080.

Narvaez, N., Y. Wang and T. McAllister. 2013. Effects of extracts of Humulus lupulus (hops) and Yucca schidigera applied alone or in combination with monensin on rumen fermentation and microbial populations in vitro. J. Sci. Food Agric. 93: 2517-2522.

Patra, A. K. and J. Saxena. 2009. The effect and mode of action of saponins on the microbial populations and fermentation in the rumen and ruminant production. Nutr. Res. Rev. 22: 204-219.

Piluzza, G., L. Sulas and S. Bullitta. 2014. Tannins in forage plants and their role in animal husbandry and environmental sustainability: A review. Grass For. Sci. 69: 32-48.

Pirondini, M., S. Colombini, L. Malagutti, L. Rapetti, G. Galassi, R. Zanchi and G. M. Crovetto. 2015. Effects of a selection of additives on in vitro ruminal methanogenesis and in situ and in vivo NDF digestibility. Anim. Sci. J. 86: 59-68.

Plaizier, J. C. and S. Li. 2013. Prediction of in vitro dry matter digestibility with the ANKOM Daisy II system of ruminant feeds using the gas production technique. Can. J. Anim. Sci. 93: 399402.

Ramos-Morales, E., G. de la Fuente, S. Duval, C. Wehrli, M. Bouillon, M. Lahmann, D. Preskett, R. Braganca and C. J. Newbold. 2017. Antiprotozoal effect of saponins in the rumen can be enhanced by chemical 
modifications in their structure. Front. Microbiol. 8, 399.

Sarnklong, C., J. W. Coneja, W. Pellikaan and W. H. Hendriks. 2010. Utilization of rice straw and different treatments to improve its feed value for ruminants: A review. Asian Australas. J. Anim. Sci. 23: 680-692.

Sebata, A., L. R. Ndlovu and J. S. Dube. 2011. Chemical composition, in vitro dry matter digestibility and in vitro gas production of five woody species browsed by Matebele goats (Capra hircus L.) in a semi-arid savanna, Zimbabwe. Anim. Feed Sci. Technol. 170: 122-125.

Soder, K. J., A. F. Brito, A. N. Hafla and M. D. Rubano. 2016. Effect of starchy or fibrous carbohydrate supplementation of orchardgrass on ruminal fermentation and methane output in continuous culture. J. Dairy Sci. 99: 4464-4475.

Soliva, C. R., A. B. Zeleke, C. Clement, H. D. Hess, V. Fievez and M. Kreuzer. 2008. In vitro screening of various tropical foliages, seeds, fruits and medicinal plants for low methane and high ammonia generating potentials in the rumen. Anim. Feed Sci. Technol. 147: 53-71.

Sudarman, A., M. Hayashida, I. R. Puspitaning, $A$. Jayanegara and $H$. Shiwachi. 2016. The use of cassava leaf silage as a substitute for concentrate feed in sheep. Trop. Anim. Health Prod. 48: 1509-1512.

Suharti, S., D. A. Astuti, and E. Wina. 2009. Kecernaan nutrien dan performa produksi sapi Peranakan Ongole (PO) yang diberi tepung lerak (Sapindus rarak) dalam ransum. JITV 14: 200207.

Theodorou, M. K., B. A. Williams, M. S. Dhanoa, A. B. McAllan and J. France. 1994. A simple gas production method using a pressure transducer to determine the fermentation kinetics of ruminant feeds. Anim. Feed Sci. Technol. 48: 185-197.
Tian, H., C. Lu, P. Ciais, A. M. Michalak, J. G. Canadell, E. Saikawa, D. N. Huntzinger, K. R. Gurney, S. Sitch, B. Zhang, J. Yang, P. Bousquet, L. Bruhwiler, G. Chen, E. Dlugokencky, P. Friedlingstein, J. Melillo, S. Pan, B. Poulter, R. Prinn, M. Saunois, C. R. Schwalm and S. C. Wofsy. 2016. The terrestrial biosphere as a net source of greenhouse gases to the atmosphere. Nature 531: 225-228.

Tsujino, R., T. Yumoto, S. Kitamura, I. Djamaluddin and D. Darnaedi. 2016. History of forest loss and degradation in Indonesia. Land Use Policy 57: 335347.

Vadiveloo, J. and J. G. Fadel. 2009. The response of rice straw varieties to urea treatment. Anim. Feed Sci. Technol. 151: 291-298.

Van Soest, P. J., J. B. Robertson and B. A. Lewis. 1991. Methods for dietary fiber, neutral detergent fiber, and nonstarch polysaccharides in relation to animal nutrition. J. Dairy Sci. 74: 3583-3597.

Yogianto, A. Sudarman, E. Wina and A. Jayanegara. 2014. Supplementation effects of tannin and saponin extracts to diets with different forage to concentrate ratio on in vitro rumen fermentation and methanogenesis. J. Indonesian Trop. Anim. Agric. 39: 144151.

Yuliana, P., E. B. Laconi, E. Wina and A. Jayanegara. 2014. Extraction of tannins and saponins from plant sources and their effects on in vitro methanogenesis and rumen fermentation. J. Indonesian Trop. Anim. Agric. 39: 91-97.

Zhou, Y. Y., H. L. Mao, F. Jiang, J. K. Wang, J. X. Liu and C. S. McSweeney. 2011. Inhibition of rumen methanogenesis by tea saponins with reference to fermentation pattern and microbial communities in Hu sheep. Anim. Feed Sci. Technol. 166: 93-100. 